\title{
A Case Report of Aplasia Cutis Congenita Type VI: Bart Syndrome
}

Florica SANDRU ${ }^{1,2}$, Catalina IORDAN ${ }^{3}$, Dana ZACIU ${ }^{3}$, Aida PETCA ${ }^{1,4}$, Mihai DUMITRASCU ${ }^{1,5}$, Adelina POPA²

\begin{abstract}
Bart syndrome is a genetic disorder that is characterized by the association of congenital localized absence of the skin (aplasia cutis), blister formation (epidermolysis bullosa), dystrophic nails and lesions of the mouth mucosa. The association of this diseases is considered a variant of aplasia cutis congenita (ACC) with epidermolysis bullosa (EB). The inheritance pattern of Bart's syndrome seems to be autosomal dominant. Aplasia cutis congenita (ACC) is a group of heterogeneous diseases representing failure of the skin to fully develop. Frieden created a classification system for ACC consisting of nine groups based on the number and location of the lesions and the presence or absence of associated malformations. In this report, we present a rare case of Bart syndrome in a newborn female baby with aplasia cutis in the lower extremities associated with lesions of epidermolysis bullosa on the face and on the hand fingers first, then located also on the thighs, and dystrophic nails.
\end{abstract}

Keywords: Aplasia cutis, Epidermolysis bullosa, Bart syndrome, genetic skin disorder, newborn.

\section{Rezumat}

Sindromul Bart este o afecțiune genetică care se caracterizează prin asocierea absenței congenitale a pielii (aplasia cutis), epidermoliză buloasă (epidermoliza bullosa), distrofii unghiale și leziuni ale mucoasei bucale. Asocierea acestor boli este considerată o variantă a aplasiei cutis congenita (ACC) cu epidermoliza bullosa (EB). Modelul de moștenire al sindromului Bart pare să fie autosomal dominant. Aplasia cutis congenita (ACC) este un grup de boli heterogene care reprezintă insuficiența dezvoltării pielii. Frieden a creat un sistem de clasificare pentru ACC format din nouă grupuri bazate pe numărul și localizarea leziunilor și prezența sau absența malformațiilor asociate. În acest raport, prezentăm un caz rar de sindrom Bart la un nou-născut de sex feminin, cu aplasia cutis la nivelul extremităților inferioare asociată cu leziuni de epidermoliză buloasă inițial pe față și pe degetele mâinii, iar apoi noi leziuni buloase localizate pe coapse și distrofii unghiale.

Cuvinte cheie: Aplasia cutis, Epidermoliză buloasă, Sindromul Bart, boală cutanată genetică, nou-născut.

\footnotetext{
${ }^{1}$ "Carol Davila" University of Medicine and Pharmacy, Bucharest, Romania

${ }^{2}$ Department of Dermatology, „Elias" Emergency University Hospital, Bucharest, Romania

${ }^{3}$ Regina Maria Hospital, Bucharest, Romania

${ }^{4}$ Department of Obstetrics and Gynecology, "Elias" Emergency

University Hospital, Bucharest, Romania

${ }^{5}$ Department of Obstetrics and Gynecology, Emergency

University Hospital, Bucharest, Romania
}

\section{Corresponding author:}

Mihai Cristian DUMITRASCU, 169 Splaiul Independentei,

Bucharest, Romania.

E-mail: drdumitrascu@yahoo.com 


\section{INTRODUCTION}

Bart syndrome is a genetic disorder that is characterized by the association of congenital localized absence of the skin (aplasia cutis), blister formation (epidermolysis bullosa), dystrophic nails and lesions of the mouth mucosa ${ }^{1,2}$. The association of this diseases is considered a variant of aplasia cutis congenita (ACC) with epidermolysis bullosa (EB) ${ }^{3}$.

Bart et al. 3 introduced in the medical literature this syndrome in 1966 in a report that presented a kinship consisting of 103 direct descendants from one proband over four subsequent generations. Among the members of this kinship, 25 members had one or more of three traits distinct traits, namely, congenital localized absence of skin involving the lower extremities, mucocutaneous blistering, and nail abnormalities. Following this report, the combination of ACC affecting the lower extremities with $\mathrm{EB}$ and nail abnormalities has been referred to as Bart syndrome ${ }^{3}$.

The disease is inherited by an autosomal dominant transmission with complete penetrance but with variable expression. This means, that the children of an affected parent that carries the gene have 50\% chan- ce of developing the disorder, although the extent to which they are affected is variable. Bart syndrome is caused by ultrastructural abnormalities in the anchoring fibrils. Genetic linkage of the inheritance of the disease points to the region of chromosome 3 near the collagen, type VII, alpha 1 gene (COL7A1) ${ }^{4}$.

In this report, we present a rare case of Bart syndrome in a newborn female baby with aplasia cutis in the lower extremities associated with lesions of epidermolysis bullosa on the face and on the hand fingers first, then located also on the thighs, and dystrophic nails.

\section{CASE REPORT}

A newborn female baby with normal birth weight (3700 grams) presented with lesions of aplasia cutis in the lower extremities associated with lesions of epidermolysis bullosa on the face and on the hand fingers and dystrophic nails. The female infant was delivered by caesarean section during the $40^{\text {th }}$ week of the mother's first pregnancy and had a 9/10 Apgar scores. The mother was 31-years-old with physiological pregnancy, negative TORCH tests and negative history of
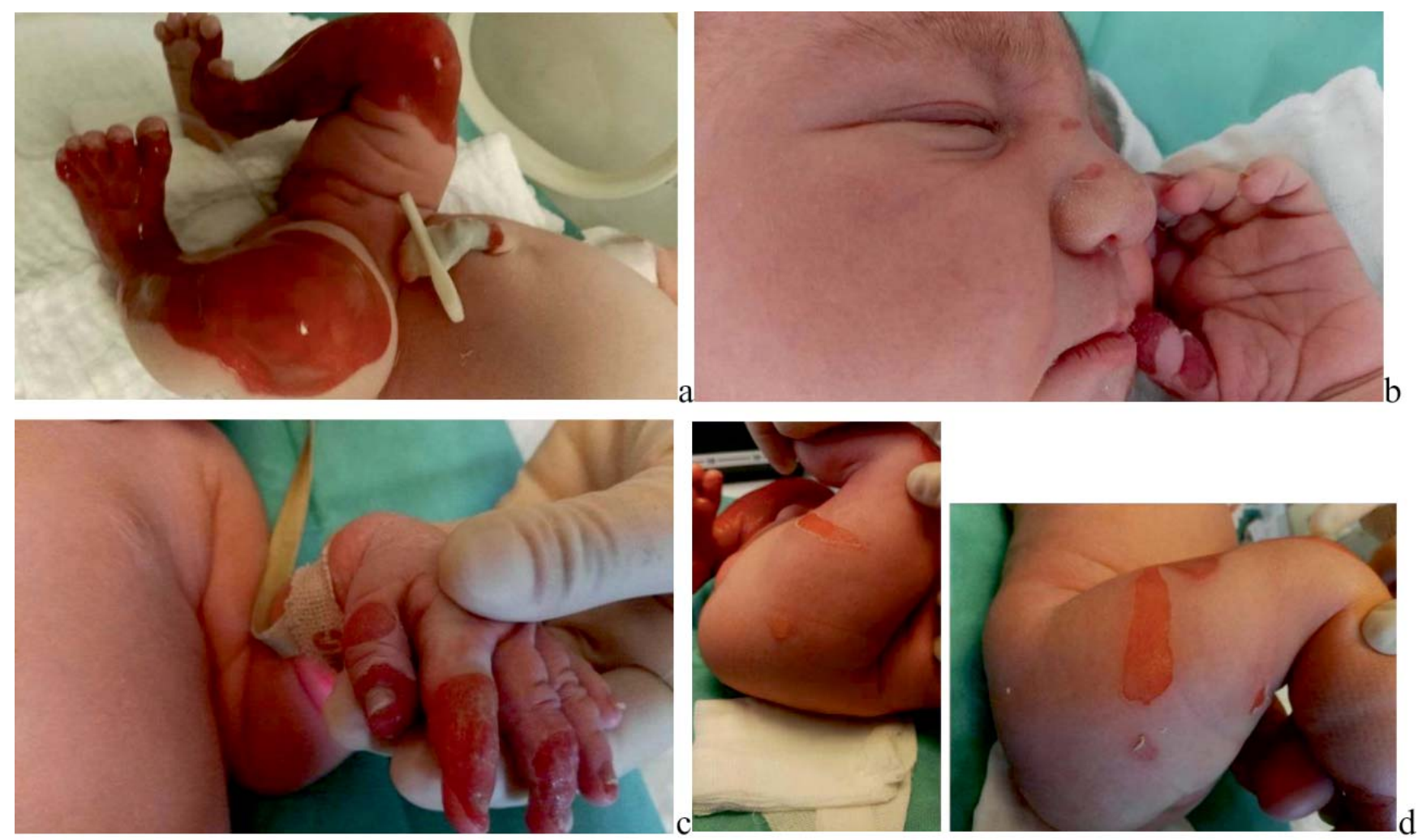

Figure 1. Aplasia cutis lesions in the lower extremities (a); Epidermolysis bullosa lesions on the face and on the hand fingers (b); Dystrophic nails (c); New bullous lesions appeared on the thighs (d). 


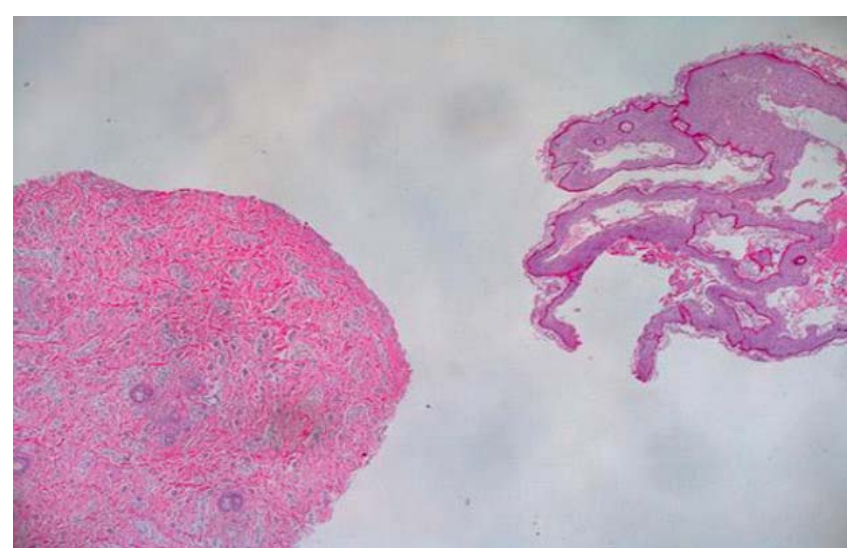

Figure 2. Dystrophic epidermolysis bullosa.

teratogen exposure. No abnormal family history was reported and both parents were apparently healthy and had no abnormalities of skin, skin appendages or mucous membrane.

The patient was referred to the newborn intensive care unit, which consulted with the Department of Dermatology because of the skin problems. On physical examination, the patient had lesions of aplasia cutisthere were symmetrical bilateral absences of skin over the anteromedial aspect of the legs, starting from the knees and extending to the dorsal and medial plantar aspect of the feet. The lesions had sharply demarcated borders covered by a red ultrathin translucent membrane, and vascular structures were easily visualized. Also, the patient associated lesions of epidermolysis bullosa-three bullous lesions on the face and multiple lesions on the hand fingers that were combined with dystrophic nails. The scalp and the mucous membranes were not affected. Systemic examination was normal. During the following days after birth, other bullous lesions appeared on the thighs, bigger than the first ones.

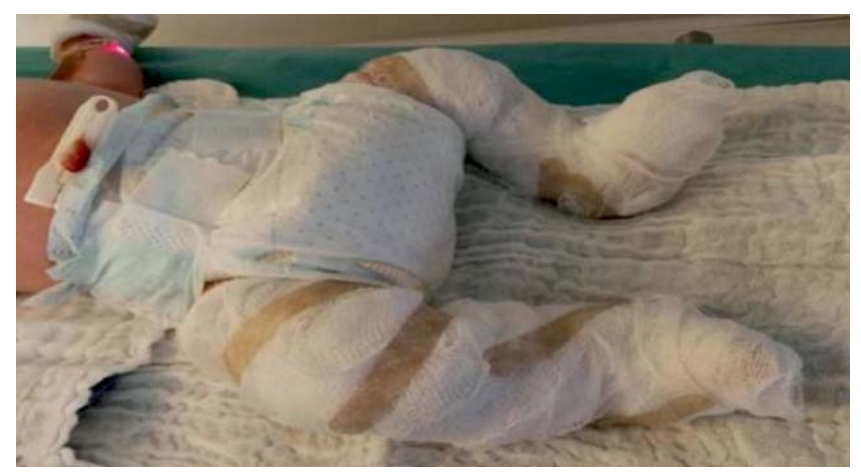

Figure 3. Sterile paraffin-impregnated dressings (Grasolind neutral).
Blistering also appeared over normal skin in response to minor trauma or friction.

Several laboratory investigations were performed; the baby's complete blood count, electrolytes, as well as liver and renal function tests were within normal limits, and serologic tests for infection were negative. The laboratory tests revealed positive C-Reactive Protein and a high level of LDH. Ophthalmological examination, abdominal and cranial ultrasound screening, and echocardiography revealed normal findings.

The diagnosis of Bart's syndrome was made on clinical presentation (the clinical triad) and skin biopsy.

Skin biopsy from ulcerated skin lesions revealed ulcerated epidermis. Upper dermis showed neutrophils, eosinophils and an occasional hair follicle. A skin biopsy was taken from a fresh blister over the thigh and showed blisters in upper dermis; PAS stain suggested the diagnosis of dystrophic epidermolysis bullosa.

Confirmation of the diagnosis is made by identifying the genetic mutation. Choral villi score was performed followed by DNA molecular analysis- Mutation in the gene encoding type VII collagen (COL7A1). The proteins produced by the COL7A1 gene, called pro- $\alpha 1$ (VII) chains, are the components of type VII collagenthat confirmed the diagnosis of Bart Syndrome.

We performed conservative treatment with -preventing the formation of new blisters, avoiding handling excessive and abrasion of the skin, prevention of complications: deformations, deforming contracts and prevention of infections. Also, thermal comfort, monitoring of vital functions, venous abort for hydration, nutrition and antibiotics (Ampicillin associated with Gentamicin, Vancomycin) were an important step in the management of the therapy. The pain control included Paracetamol, Perfalgan and Fentanyl.

Local toilet was made with chlorhexidine $0.2 \%$, diluted 1: 3 with physiological serum. We performed conservative wound care with topical antibacterial cream (Fucidin, Dexapanthenol and Cicalfat) applied twice per day and we used special sterile paraffin-impregnated dressings (Grasolind neutral), soft silicone foam antimicrobial dressings (Mepilex, Mepitel).

The evolution of aplasia cutis lesions had an epithelialization tendency, but an extension of the lesions of epidermolysis bullosa imposed prolongation of hospitalization. Also, the skin lesions were superinfected- skin cultures from the affected areas: Enterobacter aglomerans, Seratia marcescens, Klebsiella pneumoniae.

The patient returned for follow-up in our Dermato$\operatorname{logy}$ Clinic every 2 weeks for 2 months. At the 2 -month 


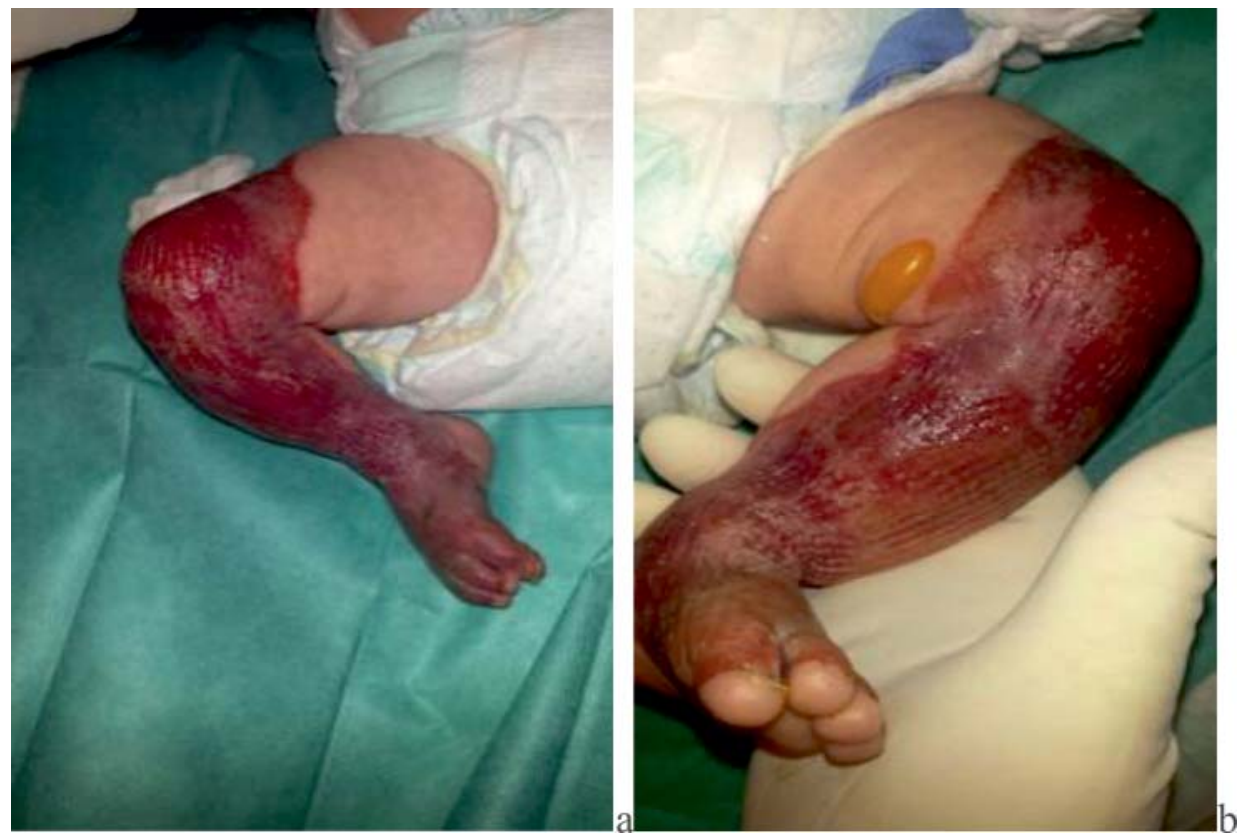

Figure 4. Evolution of aplasia cutis lesions-epithelialization tendency (a,b); In evolution-new lesions of epidermolysis bullosa (b).

follow-up visit, the patient was in good health and was well fed on formula without any complications. There was no difficulty in urination or defecation. The previous lesion had a Slow favorable evolution and healed with scarring and milia formation. These scar areas require plastic surgical reconstruction with skin grafts.

\section{DISCUSSION}

In more severe cases of Bart's syndrome, specifically those associated with junctional epidermolysis bullosa, the patient can present with other congenital anomalies, such as pyloric atresia, ureteral stenosis, renal abnormalities, rudimentary ear development, flattened nose, broad nasal root, and wide-set eyes ${ }^{5}$. However, in our case, there were no associated anomalies.

The inheritance pattern of Bart's syndrome seems to be autosomal dominant. Nevertheless, several sporadic cases have been reported ${ }^{6}$. Bart syndrome has no known underlying cause. Although, various hypotheses have been proposed, both the etiology and pathophysiology of Bart's syndrome are still much debated ${ }^{7}$. Our case was sporadic because there was neither consangu- inity between the patient's parents nor any family history of a similar lesion.

Bart syndrome is usually diagnosed because of the clinical presentation. In a few cases, analysis will need skin biopsy to settle the type of epidermolysis bullosa and genetic study to observe the exact gene mutation, and that may help us to confirm the final diagnosis. In our case, the diagnosis of Bart syndrome was formed because of the characteristic clinical presentation, including congenital localized absence of skin over the medial aspect of both lower legs, blistering of the skin, and nail dystrophy. Congenital absence of skin in Bart syndrome may follow the lines of Blaschko.

Aplasia cutis congenita (ACC) is a group of heterogeneous diseases representing failure of the skin to fully develop. Frieden created a classification system for ACC consisting of nine groups based on the number and location of the lesions and the presence or absence of associated malformations. Group six of ACC is a genodermatosis characterized by a triad of clinical manifestations: ACC that presents usually over the lower extremities, any type of epidermolysis bullosa, and nail abnormalities ${ }^{8}$. Various drugs have been implicated in 
the pathogenesis of ACC. These include methimazole, valproic acid, angiotensin-converting enzyme inhibitors, benzodiazepines, misoprostol, and cocaine ${ }^{9,10}$.

The management of Bart syndrome is generally conservative and includes wound care, allowing the affected area to declare itself in order to optimize future reconstruction, control of infection, and prevention and treatment of complications. Neither surgical nor nonsurgical methods, such as repeat Alloderm grafting or application of cultured keratinocytes, are required in many cases of Bart's syndrome. In this case, we managed our patient conservatively with topical cream twice per day and nonadhesive dressings changed every 4 days. The recovery time was similar to that in the previous literature that reported using the same methods.

The prognosis in Bart's syndrome depends on a large number of factors, like the severity of aplasia cutis, epidermolysis bullosa subtype, associated anomalies, and efficacy of treatment. Generally, the prognosis is good ${ }^{6}$. The patients have a normal life expectancy and in almost all cases they have a normal life. After all, close follow-up for serious complications like hemorrhage, infection, hypothermia, and hypoglycemia is necessary. In this case, no severe complications were seen as of the writing of this case report.

\section{References}

1. Butler DF, Berger TG, James WD, Smith TL, Stanely JR, Rodman OG (1986). "Bart's syndrome: microscopic, ultrastructural, and immunofluorescent mapping features". American Family Physician. 3 (2): 113-118. doi:10.1111/j.1525-1470.1986. tb00500.x. PMID 3513144.

2. James W, Berger T, Elston D (2005). Andrews' Diseases of the Skin: Clinical Dermatology (10th ed.). Saunders. p. 558. ISBN 978-0-7216-2921-6.

3. Bart BJ, Gorlin RJ, Anderson VE, et al. Congenital localized absence of skin and associated abnormalities resembling epidermolysis bullosa. A new syndrome. Arch Dermatol. 1966;93:296304.

4. Christiano AM, Bart BJ, Epstein EH Jr, Uitto J (1996). «Genetic basis of Bart.s syndrome: a glycine substitution mutation in the type VII collagen gene.. American Family Physician. 106 (6): 1340-2. doi:10.1111/1523-1747.ep12349293. PMID 8752681.

\section{CONCLUSIONS}

Bart's syndrome is a rare congenital skin disorder characterized by a unique clinical presentation. Looking for other associated anomalies is necessary ${ }^{6}$. In general, the syndrome has a good prognosis, but it should be managed as early as possible to reach the best outcome. Management can be conservative with relatively simple methods for rapid and optimal healing without the need for complex interventions. Close follow-up of the patient is recommended.

Genetic counseling for this rare familial disorder is extremely important for affected families. DNAbased prenatal diagnosis using Chorionic villus sampling or Amniocentesis is available for junctional and dystrophic forms of $\mathrm{EB}$, wherein the mutations have been characterized. Future avenues are currently under investigation for early prenatal diagnosis, including preimplantation genetics.

Compliance with ethics requirements: The authors declare no conflict of interest regarding this article. The authors declare that all the procedures and experiments of this study respect the ethical standards in the Helsinki Declaration of 1975, as revised in 2008(5), as well as the national law. Informed consent was obtained from all the patients included in the study.

5. Casanova JM, Martí RM, Baradad M, Egido R, Mascaró JM: Bart syndrome associated to lethal junctional epidermolysis bullosa (Herlitz form) (in Spanish). Actas Dermosifiliogr 2006; 97:658661

6. Kulalı F, Bas AY, Kale Y, Celik IH, Demirel N, Apaydın S: Type VI aplasia cutis congenita: Bart's syndrome. Case Rep Dermatol Med 2015; 2015:549825.

7. Kothari C, Doshi N, Avila A, Martin D: Visual diagnosis: newborn with absence of skin. Pediatr Rev 2014; 35:e49-e52.

8. Frieden IJ: Aplasia cutis congenita: a clinical review and proposal for classification. J Am Acad Dermatol 1986; 14:646-660.

9. Karg E, Bereg E, Gaspar L, et al. Aplasia cutis congenita after methimazole exposure in utero. Pediatr Dermatol 2004; 21:491.

10. Tasin L, Belli S, Chiodini E. Aplasia cutis congenita and methimazole. A case report and literature review. Eur J Pediatr Dermatol 2005; 15:117. 
